\title{
Study of History of Al-Bukhari on the Differences and the Relevance of the Role of Islamic Education Institutions with Building Religious Plurality in Indonesia
}

\author{
$\underline{\text { Shobirin }}^{1}$, Guntur Dwi Purwanto ${ }^{2}$, Naqiyah $^{3}$, Mohamad Anton Athoillah $^{4}$ \\ 1,2,3,4UIN Prof. KH. Syaifuddin Zuhri, Purwokerto, Indonesia \\ Email:201771027@mhs.iainpuwokerto.ac.id,201771018@mhs.iainpurwokerto.ac.id, \\ naqiyah.mukhtar@iainpurwokerto.ac.id, anton_athoillah@uinsgd.ac.id
}

\begin{abstract}
:
This article discusses the Hadith of Al-Bukhari's history about the differences and relevance of the role of Islamic educational institutions in building religious plurality in Indonesia. Indonesia is a country that has the motto bhinneka tunggal ika. The plurality of plurality is highly upheld and respected. This study was written using a qualitative method with a literature study as an approach. The type of data in this article is in the form of written narratives or documents contained in the publication of Hadith History of Al-Bukhari about the differences and related scientific works that have been published. The technique of collecting data is by tracing some related scientific publications. The analysis technique used is through the use of the takhrij al-hadith application which is followed by sharh al-hadith, both al-turathi and al-mu'assir. This article describes that the Hadith of Al-Bukhari's history regarding differences is seen as relevant to the role of Islamic educational institutions in building religious plurality in Indonesia.
\end{abstract}

Keywords:

hadith; history; differences; plurality; takhrij al-hadith

\section{Introduction}

Islam is a religion that educates its people to become people who live following the pleasure of Allah SWT (Lismijar, 2019). Islamic educational institutions are a forum for the implementation of Islamic education under the auspices of the government and certain social organizations. The existence of educational institutions is nothing but a tangible manifestation of the government's presence through programs to educate the nation's children and assistance from community organizations that provide education guarantees for the people of Indonesia. The role of Islamic educational institutions in addition to providing knowledge of Islamic religious teachings, also has an equally important role, namely building religious pluralism. In the pluralistic Indonesian nation, various religions grow and are recognized, various races; ethnicity; ethnic group; and customs very much. It is real, there can be no doubt (Kewuel et al., 2017).

Religious plurality is important to maintain national unity and integrity (Pinilih, 2018; Rusydi \& Zolehah, 2018). Religious pluralism will create harmony between religious communities, but the harmony is still limited to not equating and distinguishing the truth of a particular religion. The MUI Fatwa Number 7/MUNAS/VII/MUI/11/2005 M states that it is forbidden for Muslims to participate in matters of religious pluralism. Pluralism in the realm of religion is forbidden by the MUI if religious pluralism is interpreted that all religions are the same and the truth of each religion is relative. This is considered contrary to the teachings of Islam (Yusuf, 2019). Recognizing the truth of one religion and blaming other religions is also considered inappropriate, socially Muslims are created to be able to live together and side by 
side among fellow Muslims and adherents of other religions without mixing up the beliefs and worship of different religions. As in the word of Allah SWT which means, "Hai manusia, sesungguhnya Kami menciptakan kamu dari seorang laki-laki dan seorang perempuan dan menjadikan kamu berbangsa-bangsa dan bersuku-suku supaya kamu saling kenal mengenal. Sesungguhnya orang yang paling mulia di antara kamu di sisi Allah ialah orang yang paling takwa di antara kamu. Sesungguhnya Allah Maha Mengetahui lagi Maha teliti" (QS. Al-Hujurat: 13).

Indonesian people must be very aware of themselves as part of Indonesian citizens who live in a country area that has a very diverse or diverse community life (Masduki, 2016). This diversity of life in society is called a plurality. The life of the pluralistic Indonesian society is nothing but growing and developing from a long historical process and the distribution that has occurred for so long in the past. The diversity that exists is a form of giving freedom to the community to carry out their lives independently without coercion, as is the case for matters of religion/belief. In the Qur'an, it has been explained in Q.S. Al-Baqarah: 256: it means, "Tidak ada paksaan untuk (memasuki) agama (Islam); sesungguhnya telah jelas jalan yang benar daripada jalan yang sesat. Karena itu barangsiapa yang ingkar kepada Thaghut dan beriman kepada Allah, maka sesungguhnya ia telah berpegang kepada buhul tali yang amat kuat yang tidak akan putus. Dan Allah Maha Mendengar lagi Maha Mengetahui" (Q.S. Al Baqarah: 256).

The development of the value of plurality in the life of the Indonesian people has become a treasure trove of religious diversity, belief, culture, customs that were born so unique and rich in values. However, it is undeniable that the development of plurality also often causes conflicts during people's lives. If the conflict is handled wisely, tolerantly, and prioritizing diplomacy, it can be suppressed and vice versa if the conflict of understanding or belief is not effectively mediated to be resolved, it will increase and can lead to prolonged conflict and even violence that can take lives.

The plurality that exists in the country is certainly not only a matter of religion, belief, culture, customs, language, skin, and so on. Such pluralism must be framed in the figure of harmony and unity as a common identity of the nation and state. This discussion regarding the plurality that exists in Indonesia, is focused on the religious aspects that exist towards the religious plurality that grows in society. The development of religious plurality in Indonesia is well known, that religious activities and beliefs have been regulated and guaranteed by the government following Article 29 (2) that the state guarantees the independence of each of its residents to embrace religion. In Indonesia, there are already adherents of Islam, Hinduism, Buddhism, Protestantism, Catholicism, and Confucianism.

The development of plurality in a country is created by the order of life in the surrounding community and is also affected by the political system it adheres to. The pluralism that does not develop and the frequent occurrence of prolonged conflicts are part of the failure of the plurality value of a region or country. The failure of plurality values in society can be caused by several factors that influence it. Although religion is exoteric (shari'a) each religion is different, but esoteric (culture) is seen as a way or an effort to God. Conflicts that often occur are due to factors outside of religion itself (Yunus, 2014). In the Hadith narrated by Al-Bukhari, the Prophet Muhammad said: "Putuskanlah sebagaimana biasa kalian memutuskan perkara, karena aku tidak suka perbedaan pendapat sehingga semua manusia berada dalam kesepakatan, atau aku mati (diatas prinsip persatuan) sebagaimana para sahabatku mati". Therefore, differences must be decided to build religious plurality. 
Through these values of tolerance, the diversity of religions and beliefs will be a gift from Allah SWT to cooperate in realizing the grace of togetherness as a nation and state. (Yusuf, 2019). Teaching the values of plurality or plurality in social life needs to be instilled from an early age through the family environment and educational institutions. The success of children's education is actually in the family, which from the beginning has become an educational institution, whether they realize it or not, although its development so far has not been optimal. After the family, then the community environment and educational institutions are formal and sustainable (Puniman \& Kadarisman, 2018).

Islamic educational institutions also play a dominant role in instilling an attitude of respect for plurality or pluralism that exists in the wider community. Educational institutions are the most effective places to build a foundation of understanding and uphold the values of pluralism to be accepted and realized, so as to create a nation and state that is safe, peaceful, and tolerant. Islamic educational institutions have a very strategic position in instilling the principles of Islamic teachings that are humanist, democratic, and just to students and other madrasah residents as a generation of Muslims. (Ma'arif, 2019; Suparno, 2002). This study focuses on efforts to describe the Hadith History of Al-Bukhari about the differences and relevance of the role of Islamic educational institutions in building religious plurality in Indonesia.

\section{Research Methods}

The study method in this research is to use qualitative research with a literature review approach (Creswell, 2017). The data sources used in this study are Hadith History of AlBukhari about the differences and many related scientific works that have been published. The technique of collecting data is by tracing many related scientific publications. The analytical technique used is through the use of applications takhrij al-hadith which is followed by sharh al-hadìth, both al-turathī and al-mu'āsir.

\section{Discussion}

\subsection{Hadith narrated by Al-Bukhari about Differences}

The Hadith of Al-Bukhari's history about differences is sourced from Bukhari, with the name of the book Praiseworthy Behavior. In Chapter: The praiseworthy nature of Ali bin Abu Talib, with the hadith number 3431. The hadith reads:

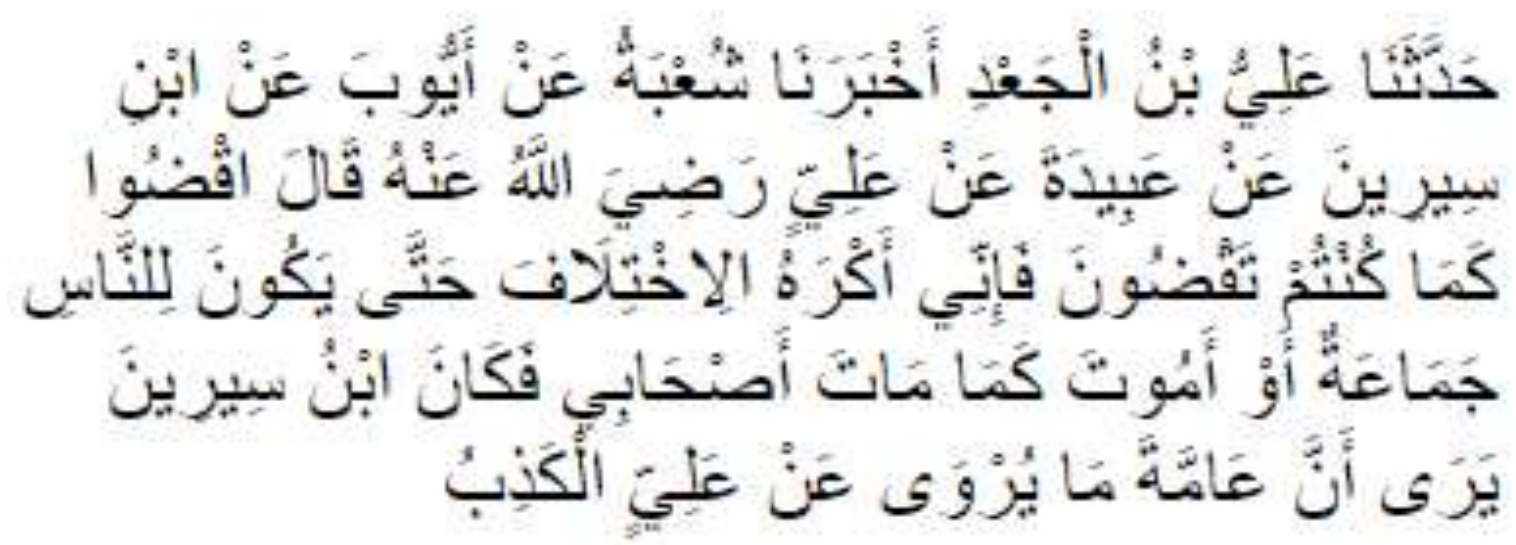

Has told us 'Ali bin Al Ja'di has told us Shu'bah from Ayyub from Ibn Sirin from 'Abidah from 'Ali radiallahu 'anhuma said; "Putuskanlah sebagaimana biasa kalian memutuskan perkara, karena aku tidak suka perbedaan pendapat sehingga semua manusia berada dalam 
kesepakatan, atau aku mati (diatas prinsip persatuan) sebagaimana para sahabatku mati". It is Ibn Sirin's opinion that in general what was narrated about 'Ali (who was at odds with his two predecessors, Abu Bakr and 'Umar bin Al Khattab, as the opinion of ar-Rafidlah) is a lie.

While the path of the 1st chain of Hadith narrated by Al-Bukhari about this difference can be described by the following scheme.

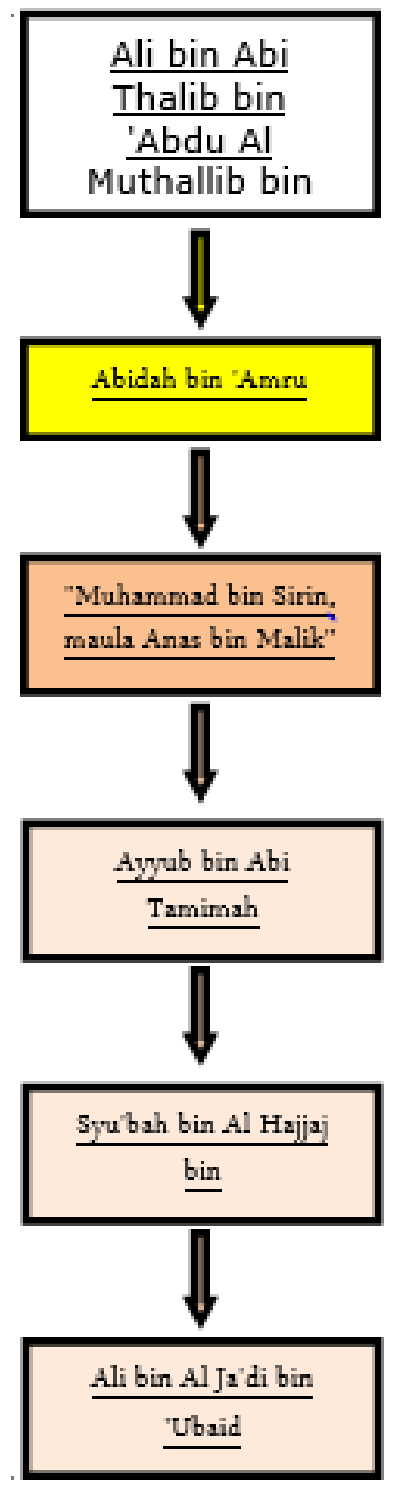

\subsection{Religious Pluralism}

The concept of religious plurality grew out of a relationship between religion, science, and culture. These three elements must be connected or linked into a single unit, namely religious plurality in the life of reality that exists in society. In constructing an understanding of religious plurality, a new scientific mentality is needed that puts forward the basic way of thinking of mankind (humanities) in general and the basic structure of building Islamic religious thinking in particular. ('ulum al-din) (Abdullah, 2020). This has been clearly stated by Allah SWT in Q.S. Al Baqarah: 256: It means: "Tidak ada paksaan untuk (memasuki) agama (Islam); sesungguhnya telah jelas jalan yang benar daripada jalan yang sesat. Karena itu barangsiapa yang ingkar kepada Thaghut dan beriman kepada Allah, maka sesungguhnya ia telah berpegang kepada buhul tali yang amat kuat yang tidak akan putus. Dan Allah Maha Mendengar lagi Maha Mengetahui" (Q.S. Al Baqarah: 256). 
Before we discuss religious plurality more broadly, it is very necessary, to begin with, a re-understanding of the meaning of religion so that it is more constructive in understanding religious plurality in society. In Arabic, religion comes from the word Ad-din, which means to control, subdue, obey, and habit. Religion is present on this earth, one of which is as a guide to the creation of a life full of order and harmony. In apparent reality, the presence of religion does not appear in a uniform face like the non-uniformity that exists in humans themselves. This can be caused by circumstances that have a positive impact on efforts to create cosmic order, as God wants diversity (plurality) as sunnatullah. (Sumbulah \& Nurjanah, 2013). Sunnatullah as a view in the context of Islam on the existence of plurality which is not only seen as a sociological reality but also as a theological fact that develops in the field.

The growing plurality of religion has indeed caused the conflict of views on the understanding of it. As has happened with the MUI fatwa regarding the prohibition of Muslims following the meaning of pluralism which holds that all religions are the same, truth is also relative (Masduki, 2016; Yusuf, 2019). The prohibition of following and acknowledging the truth of this understanding is intended as a form of MUI in protecting all Indonesian Muslims so that they do not get lost in interpreting pluralism. Pluralism is recognized for its usefulness if it is interpreted as a means of developing cooperation in the social or humanitarian and national fields.

The changes that are happening now with the term industrial revolution 4.0 and are also supported by the Covid-19 pandemic, so that they contribute to changes in human life that are increasingly diverse or plural which leads to an increasingly thick religious plurality. Changes that occur everywhere, including human knowledge, also move, grow and develop, but still bring a problem here and there. This happens because there are still those who have an understanding and belief that Islamic religious values (knowledge) are absolute, unchangeable, and transcendental (Abdullah, 2020).

Pluralistic values that recognize the diversity that exists in reality in society regardless of the nature of religious teachings themselves need to be recognized in creating a harmonious and harmonious community environment in social life. If a society does not recognize the values of religious plurality, it will facilitate the occurrence of a conflict (Hanik, 2016; Mubin, n.d.). Harmony between religious communities wherever they are or in any country, one of the keys to its success is to uphold the value of religious plurality in social life. So the values of religious plurality need to be implemented in social life with the corridor that it does not interfere with the nature of any religion or belief. As emphasized by Allah SWT in Q.S. Al Kafirun: 6 "Untukmu agamamu, dan untukku agamaku." So Muslims are asked to be able to live side by side with other people in neighboring and cooperate, in the interests of the world.

\subsection{The Important of Religious Pluralism}

Communities in Indonesia with their diversity of ancestral heritage such as customs, culture, language, religion, belief, ethnicity, and so on are a plurality that must be maintained properly. So Indonesia has been recognized as a very rich country in terms of its social plurality. The existence of pluralism has always been a benchmark for whether or not plurality is accepted (Dzakie, 2014). The pros and cons of the development of pluralism in Indonesia have led to several social and other conflicts in society. Religious plurality has the most urgent position against conflicts that are very easy to occur.

The emergence of problematic factors in society is because the process of interpreting pluralism is not quite right, the meaning of pluralism is mixed with religious pluralism in 
general. Such errors can be sourced from speakers who do not understand the meaning of pluralism as a whole and/or it can also be sourced from recipients of the information who are less precise in interpreting pluralism which leads to an acceptance of religious pluralism in society. Pluralism is an understanding that teaches to be able to accept existing differences and make these differences a strength to cooperate, not the other way around which can easily be used as the basis for a conflict.

Planting education that teaches the values of pluralism to a lesser extent has a big contribution to the lack of understanding related to plurality in society.(M. M. Saihu \& Aziz, 2020) It is well known that today's civilization is produced from the educational process several decades earlier, while the development of the world of education (level of education) of the Indonesian people is not as high or as advanced as it is today. Therefore, science (education) has a big role in the problem of plurality in society and also as an effective strategy to be able to solve it.

Problems that already exist and develop in the community can be born and grow from the process of mentoring in education that is not appropriate so that these problems exist for a long time and even become a false belief.(Primadata et al., 2019) So the misunderstanding in interpreting the values of religious plurality in life in society needs to be broken and corrected so that the community, especially Muslims, understands well, and can be a pioneer in changing a harmonious and united society.

Religious pluralism by meaning that all religions are essentially the same is an inaccurate understanding and religion is a problem that cannot be negotiated or replaced. (Dzakie, 2014; Yusuf, 2019). Pluralism which leads to religious plurality must be interpreted as a form of tolerance and religious harmony in carrying out worship according to their respective beliefs and teachings. In addition, religious plurality must be interpreted as a means to realize cooperation and work for hand in hand in realizing peace, harmony, and unity in the nation and state.

A life that is peaceful, harmonious, and full of harmony is the hope and dream of all people in various parts of any country. It seems that none of them wants conflict, conflict, let alone war that can diminish the comfort of a person's life and society. It often results in victims (Wahid, 2019). M. Amin Abdullah argued that the world of education must be able to have a model that can accommodate the local culture and maintain traditions and religious identity (S. Saihu, 2020). The role of the world of education is very important to maintain and implement the right plurality in society. These efforts can be carried out with reforms in the world of Islamic education by displaying the face of tolerant Islam, from the point of view of the philosophy of paternalism, essentialism, and progressivism. (Ma'arif, 2019).

\subsection{Building Religious Pluralism}

Hadith narrated by Al-Bukhari about differences indicates that the Prophet Muhammad did not like differences. The hadith states that differences must be resolved immediately by mutual agreement, through mutual agreement, and not only by upholding the truth of the group to be recognized by other groups. Collective agreements can be built based on acceptance of the different principles of each group/group, without eliminating one of them. Hadith narrated by Al-Bukhari about the differences: 


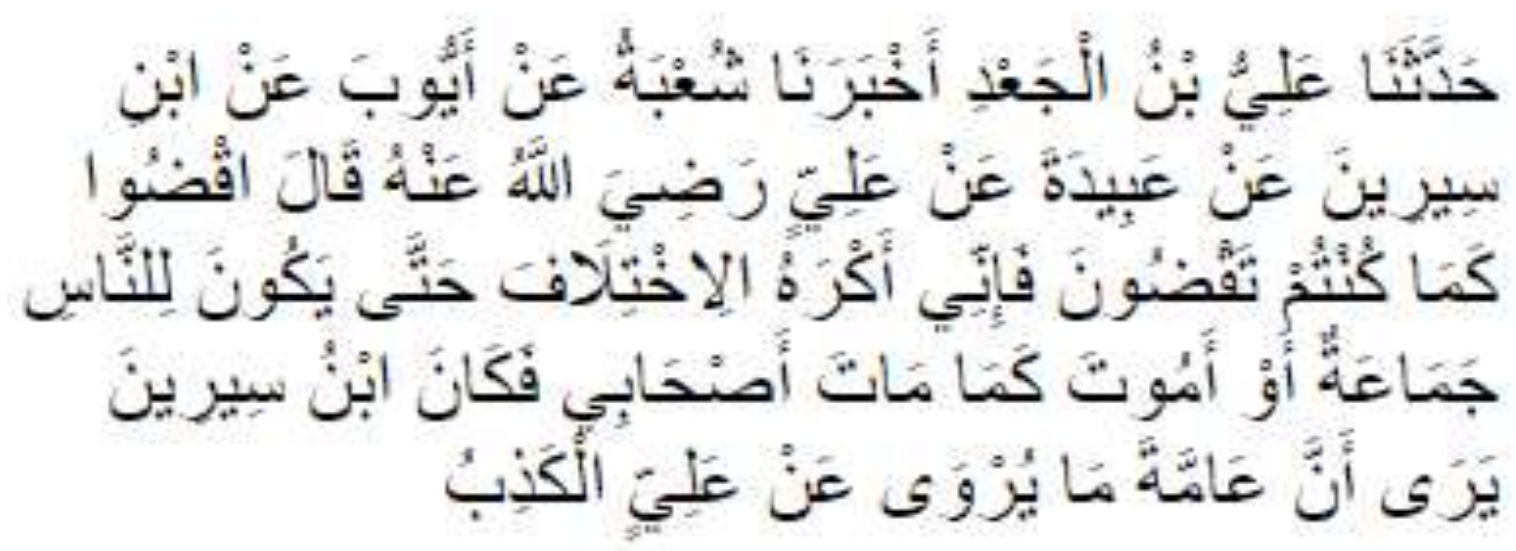

Differences will always exist if differences are not resolved through mutual agreement (Widjaja, 2019). The mutual agreement can be created through effective communication, through communication, and the coexistence of differences so that agreement will be built. The values of difference according to what is contained in the five precepts of Pancasila must be upheld, the basis of the state was formed to be able to protect and protect every group and religion that grows and develops in Indonesia. Economic growth is still an important goal in a country's economy, especially for developing countries like Indonesia (Magdalena and Suhatman, 2020). The economic condition of the population is a condition that describes human life that has economic score (Shah et al, 2020). The presence of Covid-19 as a pandemic certainly has an economic, social and psychological impact on society (Saleh and Mujahiddin, 2020). The current human civilization which is being torn apart by the Covid-19 pandemic has brought fundamental changes to every sector of human life. Humans from all levels and levels or groups are forced to adapt to new and sudden environmental situations and conditions. None of the religious (worship) activities, social, educational, economic, political, and cultural activities can be avoided from this kind of situation. A difficult situation like this must be faced with strong pluralistic values of community life, without it it is impossible for a society or a nation to get through these difficult times by remaining united.

The development of religious plurality must be built from the roots of understanding first so that the construction of knowledge and the meaning of religious pluralism is able to realize the right understanding of religious plurality in life in society. According to Abdurrahman Wahid, the concept of pluralism that can be implicit in the realm of education is to instill education to accept differences as sunnatullah so that they know each other, avoid divisions, develop cooperation by instilling a sense of mutual understanding, belonging, and being inclusive, not limiting association with anyone, but still believe in the truth of one's own religion by not equating belief in total. In the perspective of Islamic religious education, pluralism education has a harmony that is oriented to the formation of noble personalities and morals based on the Qur'an and Al-Hadith and seeks to instill values of tolerance in students from an early age that is sustainable by developing a sense of mutual respect. understanding and mutual respect for adherents of other religions (Cahyadi, 2017).

The strategy that needs to be applied to treat the increasing trend of conservatism and exclusivity in religious education in the modern era is to strengthen the field of how to weld, connect, and link a solid relationship between the three. (Abdullah, 2020). The three efforts are directed at how to provide guidance and understanding to students to recognize and understand the values of authenticity to be able to support life together (peaceful coexistence; al-ta'ayus al-silmi) so that these values can be maintained and developed by students in their social life. 
Instilling an understanding of religious plurality in the Islamic education environment must involve all madrasah citizens, such as educators and education staff, parents, and students. Students as learning objects must be given examples and involved in any plurality education, either directly or indirectly. Islamic educational institutions can provide their role through learning activities of diverse plurality values by involving the values contained in the Hadith History of Al-Bukhari about this difference.

The development of a pluralistic attitude in students in this current era absolutely must be carried out by all Islamic educational institutions throughout Indonesia. The values of tolerant Islamic teachings can be displayed through the curriculum compiled by Islamic educational institutions with the aim and emphasis on understanding and attitudes of students to be able to live in the context of real religious and cultural differences in society. (Mubin, n.d.). When students receive early intake and inculcate the values of unity and unity for pluralism in Indonesia, a strong nation and state will be built by upholding the values of religious plurality in the community (Guntoro, 2019).

The learning process of religious science (Islam) which has developed rapidly can be used as a step forward and effective in providing education of pluralism values to students which are made explicit in learning materials and teaching materials in the Islamic education environment. In addition to being more effective, it is considered that it will also be easy to monitor the progress and temporary results of what students have learned. Pluralism values can be given to students according to the development (age) and level of the educational institution.

The Islamic education curriculum as a guideline is even used as the Implementation Operational Standard (SOP) for education and learning in educational institutions, it must be able to be structured and developed dynamically according to the current situation and circumstances, such as during the Covid-19 pandemic, objectively aimed at solving life problems. Developments such as the improvement and formation of pluralism values in students, and must also be developed comprehensively to accommodate all interests in the context of developing the values of Islamic religious knowledge, technology, and science in general.

As a concrete step in solving existing problems related to the low cultivation and formation of pluralism values in students in the previous era of educational development which was only partially implemented in certain educational institutions, actions that must be carried out as an effort to save generations of Muslims and future generations of the nation, the values of pluralism must be included in every program and activity of students. Be it in curricular educational programs/activities or during extracurricular programs/activities.

The values of plurality Islamic education that is displayed in the curriculum development of educational institutions aimed at providing understanding and embodiment of religious plurality in the Islamic education environment can be emphasized on a complete understanding of the principles of religious plurality. These principles include (Ma'arif, 2019; Mubin, n.d.; S. Saihu, 2020):

1. Preserving community culture,

2. Growing the values of life,

3. Foster friendship among students,

4. Develop the mutual understanding,

5. Promote openness and interactive dialogue,

6. Prioritizing existing pluralism/diversity, 
7. Religious education with a muqaron approach,

8. Development of social intelligence for interfaith education,

9. Procurement of interfaith roadshow programs,

10.Provision of Spiritual Work Camp (SWC) programs,

11.Procurement of sahur program on the road,

12.Faith education with an inclusive approach.

The development of educational programs at Islamic educational institutions is a real effort in instilling and forming the right understanding in students about the fundamental Islamic values that support religious plurality in society, not hating and considering opponents for all differences. It has been emphasized by Allah SWT repeatedly in several verses of the Qur'an that, (Yusuf, 2019):

1. There is no compulsion to embrace the religion of Allah (Islam),

2. There is no mixing of one religion, that is for you your religion and me my religion,

3. Allah does not forbid humans (Muslims) to do good and be fair to people of different beliefs,

4. Islam requires doing good and respecting the rights of neighbors, regardless of the neighbor's religion.

Indonesia is an example of a multicultural country (Supriatin \& Nasution, 2017). The identity of the Indonesian nation which has a wealth of culture, ethnicity, language, customs, race, and religion really needs to be preserved and maintained. However, on the other hand, it becomes a potential part that can trigger conflict in the community. Encouraged by belief and belief in the truth of their religion and dictating other religions, it is the fault of each adherent, in which not understanding the importance of the value of religious plurality in a nation and state can have an impact on disturbing a peaceful life and working together in unity. Pluralism education in realizing good religious plurality by not interfering in the affairs of the faith of each religion, not judging that all religions are the same, and maintaining inter-religious harmony is certainly the right choice in implementing the principle of religious plurality in society.

\section{Conclusion}

The content of the Hadith of Al-Bukhari's history about differences in the hadith number 3431 teaches the values of resolving differences by mutual agreement. Differences that exist in the community must be resolved, without causing cases and victims if it starts from communication and mutual agreement. The resolution of differences can be resolved as well as the settlement of a case in general, namely through understanding differences and acknowledging that differences will always exist as long as humans have their paths and goals in life. The settlement of cases over a difference of opinion can be started from within each individual, through the cultivation of values and an understanding of pluralism in Indonesia.

Islamic educational institutions that have a central role in educating and producing generations of people who have good morals, should be prepared to become institutions that form Islamic character and character and are tolerant of the characteristics that exist in Indonesia from the ideology of the nation, language, customs, ethnicity, race, skin, dialect, religion, belief, and others. This kind of Islamic educational institution has a stronger foundation than education through family, community, and environment. Understanding of the values of Islamic teachings must be fully and comprehensively understood by students so that they become strong Muslim individuals and also recognize the existence of other religions or beliefs that coexist in Indonesia, upholding the motto Bhinneka Tunggal Ika as a forum to 
form a nation that recognizes the existence of religious plurality as the wealth of the Indonesian nation. Religious plurality that is not quite right is when interpreting religious pluralism as an understanding that judges that every religion is the same and that truth is relative to it. Whereas supposedly, religious pluralism is interpreted as an understanding that recognizes each religious teaching is different according to belief in God and every religion has its way. Therefore, every religious adherent must respect each other for existing differences, uphold the motto of Indonesian pluralism, namely "Bhinneka Tunggal Ika", strengthen harmony between religious communities through cooperation, mutual assistance, mutual assistance, and uphold tolerance between religious communities.

The Hadith of Al-Bukhari's history about differences has relevance to the role of Islamic educational institutions in building plurality in Indonesia. This hadith teaches the handling of a case/difference through mutual agreement, so the role of Islamic educational institutions in educating the nation's generation with science and religion is considered very appropriate. Human resources who are built with intellectual qualities and good understanding have a strategic role in building the right understanding and practice of religious plurality in students and their families effectively. The principles of religious plurality respect each other, respect each other, live side by side without interfering with the nature of religion, cooperate, and uphold religious tolerance. Therefore, the cultivation of religious pluralism values will be easily and effectively built with the dominant role of Islamic educational institutions.

\section{References}

Abdullah, M. A. (2020). Multidisiplin, Interdisiplin, dan Transdisiplin : Metode Studi Agama dan Studi Islam di Era Kontemporer (Cetakan I). IB Pustaka.

Cahyadi, A. (2017). Konsep pluralisme abdurrahman wahid dalam perspektif pendidikan agama islam.

Creswell, J. W. (2017). Research Design (Pendekatan Kualitatif, Kuantitatif, dan Mixed) (VI). Pustaka Pelajar.

Dzakie, F. (2014). Meluruskan Pemahaman Pluralisme Dan Pluralisme Agama Di Indonesia. Al-AdYaN.

Guntoro, M. (2019). Menanamkan Semangat Nasionalisme \& Patriotisme Pada Generasi Muda Di Tengah Pluralisme. CENDEKIA Jaya, 1-9. http://jurnal.untagcirebon.ac.id/index.php/cendekia-jaya/article/view/31

Hanik, U. (2016). Pluralisme Agama Dan Kerukunan Hidup Beragama. In Jurnal Pemikiran Keislaman (Vol. 26, Issue 2, pp. 431-443). https://doi.org/10.33367/tribakti.v26i2.225

Kewuel, H. K., Budiyanto, A., Fajar, Y., \& Kumoro, N. B. (Eds.). (2017). Seri Studi Kebudayaan 1 Pluralisme Multikulturalisme dan Batas batas Toleransi. Program Studi Antropologi Fakultas Ilmu Budaya, Universitas Brawijaya.

Lismijar. (2019). Pembinaan Sikap Ikhlas Menurut Pendidikan Islam. Intelektualita, 5(02), 12.

Ma'arif, S. (2019). PENDIDIKAN ISLAM PLURALIS Menampilkan Wajah Islam Toleran dalam Pendidikan Islam. TOLERANSI: Media Ilmiah Komunikasi Umat Beragama, 10(2), 176. https://doi.org/10.24014/trs.v10i2.7084

Magdalena, S., Suhatman, R. (2020). The Effect of Government Expenditures, Domestic Invesment, Foreign Invesment to the Economic Growth of Primary Sector in Central Kalimantan. Budapest International Research and Critics Institute-Journal (BIRCIJournal). Volume 3, No 3, Page: 1692-1703.

Masduki, H. (2016). Pluralisme dan Multikulturalisme dalam Perspektif Kerukunan Antar Umat Beragama. Dimensi, 9(1), 15-23.

Mubin, F. (n.d.). OSF _ Wawasan Pluralisme dalam Kurikulum Pendidikan Islam.pdf. 
Pinilih, S. A. G. (2018). Aktualisasi Nilai-Nilai Pancasila Terhadap Hak Atas Kebebasan Beragama Dan Beribadah Di Indonesia. Masalah-Masalah Hukum, 47(1), 40-46. https://doi.org/10.14710/mmh.47.1.2018.40-46

Primadata, A. P., Sosiologi, J., Soedirman, U. J., Inklusif, P., \& Indonesia, P. (2019). Merajut toleransi melalui pendidikan inklusif. 3(12), 69-74.

Puniman, A., \& Kadarisman, K. (2018). PENDIDIKAN ANAK DALAM PERSPEKTIF ISLAM. Alpen: Jurnal Pendidikan Dasar. https://doi.org/10.24929/alpen.v1i1.1

Rusydi, I., \& Zolehah, S. (2018). Makna Kerukunan Antar Umat Beragama Dalam Konteks Keislaman Dan Keindonesian. Journal for Islamic Studies, 1(1), 170-181. https://doi.org/10.5281/zenodo.1161580

Saihu, M. M., \& Aziz, A. (2020). Implementasi Metode Pendidikan Pluralisme Dalam Mata Pelajaran Pendidikan Agama Islam. Belajea; Jurnal Pendidikan Islam, 5(1), 131. https://doi.org/10.29240/belajea.v5i1.1037

Saihu, S. (2020). Pendidikan Pluralisme Agama: Kajian tentang Integrasi Budaya dan Agama dalam Menyelesaikan Konflik Sosial Kontemporer. Jurnal Indo-Islamika, 9(1), 67-90. https://doi.org/10.15408/idi.v9i1.14828

Saleh, A., Mujahiddin. (2020). Challenges and Opportunities for Community Empowerment Practices in Indonesia during the Covid-19 Pandemic through Strengthening the Role of Higher Education. Budapest International Research and Critics Institute-Journal (BIRCI-Journal). Volume 3, No 2, Page: 1105-1113.

Shah, M. M., et al. (2020). The Development Impact of PT. Medco E \& P Malaka on Economic Aspects in East Aceh Regency. Budapest International Research and Critics Institute-Journal (BIRCI-Journal). Volume 3, No 1, Page: 276-286.

Sumbulah, U., \& Nurjanah, N. (2013). Pluralisme agama: Makna dan lokalitas pola kerukunan antarumat beragama. In Pluralisme Agama Makna dan Lokalitas Pola Kerukunan Antarumat Beragama. http://103.193.19.206/index.php/alfikra/article/viewFile/3848/2384

Suparno, P. (2002). Reformasi Pendidikan sebuah Rekomendasi. Kanisius.

Supriatin, A., \& Nasution, A. R. (2017). IMPLEMENTASI PENDIDIKAN MULTIKULTURAL DALAM PRAKTIK PENDIDIKAN DI INDONESIA. Elementary: Jurnal Ilmiah Pendidikan Dasar. https://doi.org/10.32332/elementary.v3i1.785

Wahid, A. (2019). PENDIDIKAN PLURALIS-MULTIKULTURAL: Upaya Membangun Kaharmonisan Antar Sesama. AL-WIJDÁN: Journal of Islamic Education Studies.

Widjaja, F. I. (2019). Pluralitas Dan Tantangan Misi : Kerangka Konseptual Untuk Pendidikan Agama. Regula Fidei: Jurnal Pendidikan Agama Kristen, 4(1), 1-13.

Yunus, F. M. (2014). Konflik Agama Di Indonesia Problem Dan Solusi Pemecahannya. Substantia.

Yusuf, S. E. (2019). Islam - Negara - -NU (F. Rahman (Ed.)). Titian Illahi Press. 